\title{
Paired Box Protein Pax-6
}

National Cancer Institute

\section{Source}

National Cancer Institute. Paired Box Protein Pax-6. NCI Thesaurus. Code C75890.

Paired box protein Pax-6 (422 aa, $47 \mathrm{kDa}$ ) is encoded by the human PAX6 gene. This protein plays a role in transcription. 